\title{
A Monetary Analysis of the Administration's Budget and Economic Projections
}

\author{
KEITH M. CARLSON
}

T.

HE administration's budget proposals and economic report, presented to Congress and the nation in early February, have generated considerable controversy. ${ }^{1}$ The prospect of historically large deficits through 1987 has especially unsettled many observers. Many question the plausibility of the administration's economic forecast, which they consider too optimistic.

Economic forecasts have always been a critical part of the budget process. One can see, however, how their importance is magnified in an inflationswollen economy. A re-estimate of GNP growth by only 1 percent, for example, results in a change of $\$ 13$ billion in federal budget receipts within two years. ${ }^{2}$ In addition, federal expenditures in recent years have become more sensitive to the pace of inflation and output, as the number of inflationindexed programs and income-security programs, which automatically change in response to economic conditions, has increased.

Aside from the budget issue, the administration's projections are of general interest because they reflect the philosophy that guides the administration's economic policies. This year's budget and economic report provide the first detailed statement of the administration's economic philosophy. One key difference from the previous administration's philosophy is in the interpretation and role of monetary actions in the determination of economic events.

\footnotetext{
1Budget of the United States Govenment for Fiscal Xear 1983 (hereafter referred to as Fiscal 1983 Budget) and the 1982 Economic Report of the President, which also includes the 1982 Amulal Report of the Council of Fconomic Advisers (hereafter referred to as CEA Report).

'See Fiscal 1983 Budget, p. 29.
}

This article analyzes the role of monetary actions in the current administration's economic framework. The discussion evaluates the consistency of the administration's economic projections, given the structure of the economy and past experience with lags in the effect of economic policy. The basis for this evaluation is a monetary model of the U.S. economy developed at the Federal Reserve Bank of St. Louis. ${ }^{3}$ The implications of the analysis also are applied to the federal budget outlook.

\section{MONETARY ANALTSE AND ThE WCONONIC IERORT}

The Economic Report of the President and The Annual Report of the Council of Economic Advisers (CEA Report) together provide a concise summary of the economic philosophy behind the administration's decision-making. President Reagan's report devotes relatively little space to the subject of monetary policy, although the president states support for ". . . a policy of gradual and less volatile reduction in the growth of the money supply." 4 This support contrasts with President Carter's statement a year earlier" "... that public opinion not hold the Federal Reserve to such a rigid form of monetary targeting as to deprive it of the flexibility it needs to conduct a responsible monetary policy." 5

The most explicit discussion of the role of monetary actions in the administration's economic framework is in the CEA Report. For example, in the opening chapter, which summarizes current economic conditions, the CEA singles out the varying

\footnotetext{
${ }^{3}$ For details of this model, see the appendix.

${ }^{4} 1982$ Economic Report of the President, p. 8.

51981 Economic: Report of the President, p. 13.
} 
and generally restrictive rate of monetary expansion as the chief culprit responsible for the economy's unsatisfactory performance in the $1979-81$ period. The CHA goes on to say that "continued monetary restraint and a reduction of the within-year variability of money growth ... are necessary both to reduce inflation and provide the basis for sustained economic growth."6

The CEA Report's overall theme is that the federal govemment's role in economic affairs should be reduced. Consistent with that theme is a program to control inflation, which, as the CEA states forcefully, is essentially a monetary phenomenon. Thus, ". . a decrease in money growth is the necessary strategy to end inflation."7 In light of the important role that expectations play in the inflationary process, the CEA is very specific: "For the Federal Reserve, this means setting money growth targets consistent with a sustained decrease in the rate of inflation and then adhering to those targets." 8

After establishing these guidelines for an antiinflationary monetary policy, the CEA details the economic prospects for 1982,1983 and beyond. Assumptions about money growth, however, do not play an explicit role in its economic forecasts. Instead, the CEA's forecasts follow the traditional "adding-up" approach typical of previous CEA Reports; that is, the activity of individual sectors are forecast and summed to obtain an aggregate forecast. Oddly enough, the CEA, after emphasizing the connection between money growth and nom inal magnitudes like GNP and the price level, and recognizing the relationship between deviations of money growth from trend and the movements of real $\mathrm{GNP}$, slights the role of money growth in their projections, particularly for 1982 and $1983 .^{9}$

\footnotetext{
61982 CEA Report, pp. 2425.

${ }^{7}$ bidid., p. 55 .

${ }^{8}$ Hhid., pp. 59-60.

${ }^{9}$ The CFA attempts to correct for this oversight. It notes that:

Concems have been expressed that the Federal Reserve's targets for money grow th are not compatille with the vigorous uptum in economic activity envisioned late in 1982 . . We believe that such fears, while understandable on the basis of reeent history and policies, are unjustified ins light of ctrrent policies and the Administration's determination to carry then throwgh. (1982 CEA Report, p. 25.
}

This statement contrasts sharply with a statement found elsewhere in its report:

Indeed, changes in the trend of the growth rate of nominal GNP over the period 1960 to 1981 are altiost entrely attribatable to changes in the trend of the growth me of the money stock (M1), as opposed to changes in the trend of the growth mate of velocity (Chart 3-3). (1982 CEA Report, p. 63.)

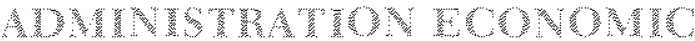

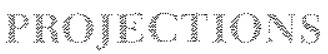

Ever since enactment of the Congressional Budget and Impoundment Control Act of 1974 (hereafter referred to as the Control Act), the in" cumbent administration has been required each year to present five-year projections of the federial budget. Thus, the current budget and economic reports cover the period through 1987.

The administration also must set five-year numerical goals for several key economic indicators under the provisions of the Full Employment and Balanced Growth Act of 1978 (Humphrey-Hawkins). This act originally specified the following goals: an unemployment rate of 4 percent and a rate of increase in consumer prices of 3 percent by 1983 , and an interim goal for federal outlays to equal 21 percent of GNP by 1981. However, the act allowed a change in this timetable if deemed necessary, and, in Jannary 1980, President Carter extended the timetables for unemployment to 1985 and for inflation to 1988 .

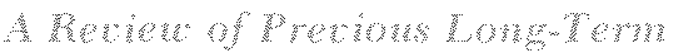 proterions}

Incumbent administrations have been presenting Iong-term economic projections since the passage of the Control Act in 1974. Table 1 summarizes these projections. ${ }^{10}$ They represent the efforts of three different administrations: President Ford's, in 197577, President Carter's in 1978-81 and President Reagan's in early 1982.

The table indicates that, for each administration, the one-year forecasts have been quite accurate for all of the indicators. ${ }^{\mathrm{t}}$ In fact, the record for GNP is good as far as four years ahead. For all the other major indicators, the forecasts tend to deteriorate beyond the two-year horizon. This may reflect the practice

\begin{tabular}{|c|c|c|c|c|}
\hline \multicolumn{5}{|c|}{ 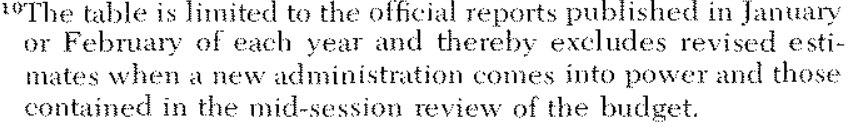 } \\
\hline \multicolumn{5}{|c|}{ the root-mean-squared erros for tabe 1 are as follows: } \\
\hline & GNP & $\begin{array}{l}\text { Renl } \\
\text { GNP }\end{array}$ & $\begin{array}{c}\text { GNP } \\
\text { defator }\end{array}$ & $\begin{array}{c}\text { Unemploynent } \\
\text { rate }\end{array}$ \\
\hline 1 year ahead & 0.92 & 1.00 & 0.97 & 0.22 \\
\hline 2 years alload & 1.01 & 1.32 & 1.72 & 0.45 \\
\hline 3 yeams nheabl & 1.14 & 2.77 & 2.63 & 1.16 \\
\hline 4 years ahead & 0.98 & 3.72 & 3.59 & 1.75 \\
\hline $5 \mathrm{y}$ & 2.46 & 4.45 & 4.88 & 1.97 \\
\hline 6 year & 2.16 & 5.16 & 5.10 & 2.29 \\
\hline
\end{tabular}




\section{Table 1}

\section{Administration Economic Projections (percent)}

\begin{tabular}{|c|c|c|c|c|c|c|c|c|c|c|c|c|c|}
\hline Date ot foredst & 1975 & 1976 & 1977 & 1978 & 1979 & 1880 & 1981 & 1982 & 1983 & 1984 & 1985 & 1986 & 1987 \\
\hline \multicolumn{14}{|l|}{ GNP. } \\
\hline Early 1975 & 72 & 126 & 124 & 120 & 108 & 108 & в & & & & & & \\
\hline 1976 & & 124 & 122 & 124 & 119 & 109 & 91 & & & & & & \\
\hline 1977 & & & 110 & 113 & 116 & 105 & 29 & 64 & & & & & \\
\hline 1978 & & & & 110 & 112 & 108 & 105 & 96 & 8.5 & & & & \\
\hline 1979 & & & & & 113 & 95 & 101 & 94 & 79 & 63 & & & \\
\hline 1980 & & & & & & 83 & 107 & 128 & 129 & 120 & 110 & & \\
\hline 1981 & & & & & & & 114 & 131 & 123 & 118 & 110 & 102 & \\
\hline 1982 & & & & & & & & 81 & 115 & 102 & 97 & 92 & 90 \\
\hline Aclualt & 60 & 109 & 116 & 124 & 120 & 80 & 114 & & & & & & \\
\hline \multicolumn{14}{|l|}{ neal GNP } \\
\hline Eary 1975 & 3.3 & 48 & 56 & 65 & 65 & 65 & & & & & & & \\
\hline 1976 & & 62 & 51 & 50 & 65 & 65 & 49 & & & & & & \\
\hline 1977 & & & 52 & 51 & 59 & 35 & 30 & 35 & & & & & \\
\hline 1978 & & & & 47 & 48 & 48 & 50 & 41 & 42 & & & & \\
\hline 1979 & & & & & 33 & 25 & 42 & 47 & 44 & 34 & & & \\
\hline 1980 & & & & & & 0.6 & 17 & 48 & 50 & 49 & 47 & & \\
\hline 1981 & & & & & & & 09 & 35 & 35 & 37 & 37 & 37 & \\
\hline 1982 & & & & & & & & 02 & 5.2 & 50 & 47 & 44 & 43 \\
\hline Actual & 14 & 54 & 5.5 & 48 & 32 & 102 & 20 & & & & & & \\
\hline \multicolumn{14}{|l|}{ Price deflatol } \\
\hline Eary 1975 & 108 & 75 & 65 & 51 & 41 & 40 & 8 & & & & & & \\
\hline 1976 & & 59 & 62 & 61 & 50 & 42 & 40 & & & & & & \\
\hline 1977 & & & 5.6 & 59 & 54 & 47 & 38 & 28 & 3 & & & & \\
\hline 1978 & & & & 61 & 62 & 57 & 52 & 47 & 42 & 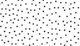 & & & \\
\hline 1979 & & & & & 77 & 68 & 57 & 45 & 34 & 28 & & & \\
\hline 1980 & & & & & & 89 & 88 & 82 & 14 & 68 & 61 & & \\
\hline 1981 & & & & & & & 10.5 & 93 & 85 & 78 & 10 & 63 & \\
\hline 1982 & & & & & & & & 79 & 60 & 50 & 47 & 46 & 45 \\
\hline Actuat & 93 & 5.2 & 58 & 73 & 8.5 & 90 & 92 & & & & & & \\
\hline \multicolumn{14}{|c|}{ Unemployment rate } \\
\hline Eary 1975 & 81 & 19 & 75 & 69 & 62 & 55 & 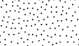 & & & & & & \\
\hline 1976 & & 77 & 69 & 64 & 58 & 52 & 49 & & & & & 8 & \\
\hline 1977 & & & 73 & 66 & 57 & 49 & 48 & 47 & & & & & \\
\hline 1978 & & & & 63 & 59 & 54 & 50 & 45 & 41 & & & & \\
\hline 1979 & & & & & 60 & 62 & 57 & 49 & 42 & 40 & & & \\
\hline 1980 & & & & & & 70 & 74 & 68 & 50 & 51 & 83 & & \\
\hline 1981 & & & & & & & 78 & 75 & 71 & 67 & 63 & 60 & \\
\hline 1902 & & & & & & & & 89 & 79 & 71 & 64 & 38 & 53 \\
\hline Actual & 85 & 77 & 11 & 61 & 58 & 11 & 76 & & & & & & \\
\hline
\end{tabular}

As of February 1982 


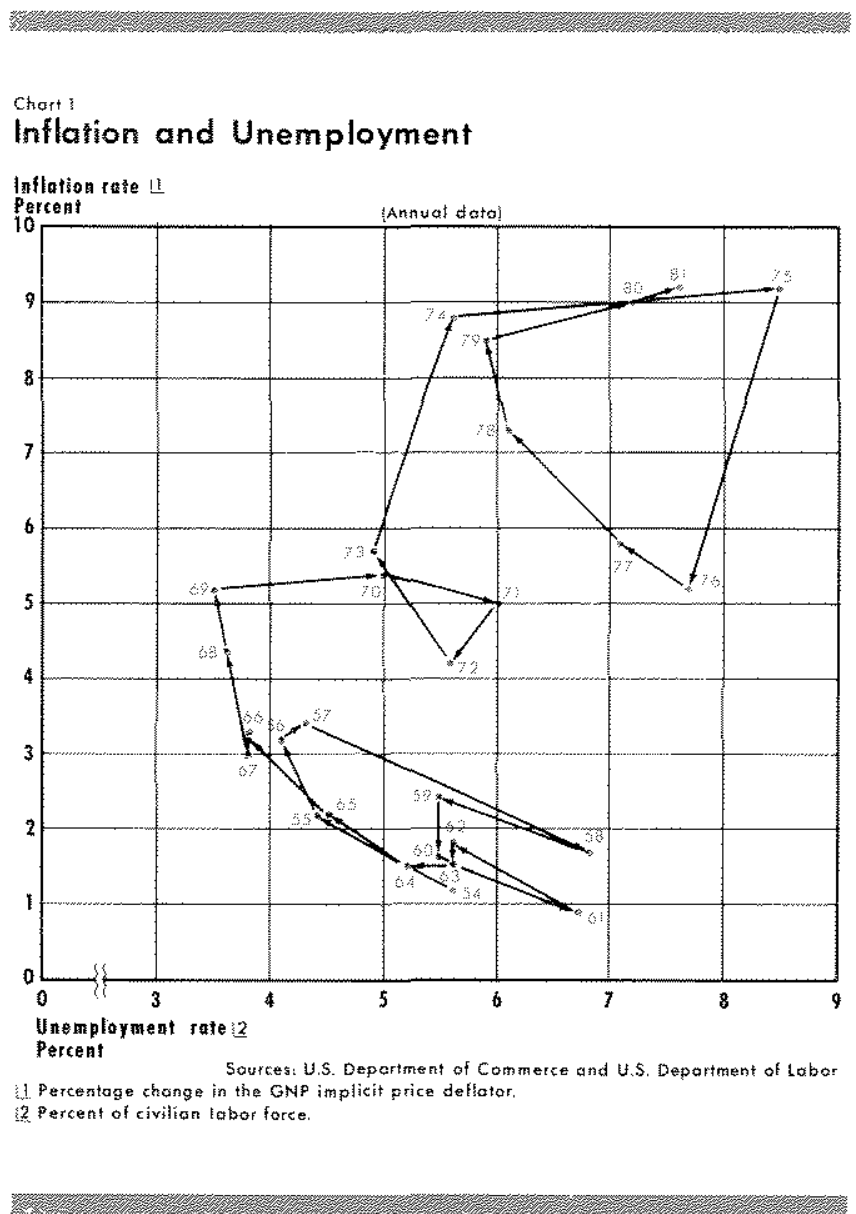

whereby assumptions for the current and next year are called "forecasts," but beyond the next year are labeled "projections consistent with moving gradually toward relatively stable prices and maximum feasible employment." For the longer term, these projections seemingly ignore or serionsly misjudge some fundamental economic constraints.

The failure of the U.S. economy to achieve relative price stability and "full employment" is obvious when one compares the projection record for these two indicators with actual performance. (For additional historical perspective, see chat 1.) Since the start of publishing long-term projections, each administration has projected a general decline of both inflation and unemployment. The actual performance of the economy, of course, has been far different. Though the rate of inflation declined from 1975 to 1976 , it has accelerated on an annual average basis each year since then. The memployment rate did fall from 1975 through 1979 , but since then has risen sharply. Such persistent forecast errors are probably a reflection of the fact that each administration gives insufficient weight to the long-term effects of its
$+$

economic policies. According to the most recent CEA report, "The events of the past 15 years are a good illustration of the danger of pursuing economic policies based on short-run analysis and focused on immediate problems. Sound policy requires enphasis on a time horizon during which the sometimes lengthy, and usually unpredictable, lags in economic processes can work."12

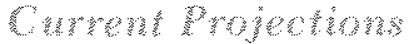

Table 2 summarizes the Reagan administration's economic projections. The nominal GNP goal for fourth quarter 1987 is $\$ 5,248$ billion, which would mean a 9.8 percent average annual rate of increase from 1981 to 1987 . This rate would be distributed as a 4.4 percent rate of expansion in real $G N P$ and a 5.2 percent rate of increase in the GNP deflator. In 1987 , according to these projections, real GNP would be growing at a 4.3 percent rate, the GNP deflator would be rising at a 4.4 percent rate and the unemployment rate would decline to 5.2 percent by the fourth quarter.

As a part of its program, the administration has proposed a budget plan aimed at a year-by-year reduction in the size of the federal deficit. Federal outlays are projected to decline to 19.7 percent of GNP in fiscal 1987 compared with an estimated 23.5 percent in fiscal 1982. More importantly, however, the administration announced its support of a monetary policy that will produce continued gradnal reductions in the rate of monetary growth.

From the fonth guater of 1979 to the fourth guater of 1980 , MI (currengy plus checkable deposits) grew at at 7.3 percent anmal rate. The Administration assumes a gradual but steady reduction in the growth of money to one halt that rate by 1986.73

The CEA notes that infationary expectations must adjust speedily to the anti-inflationary monetary regime in order to attain these economic goals. ${ }^{14}$

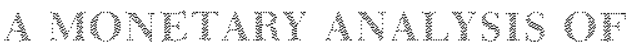

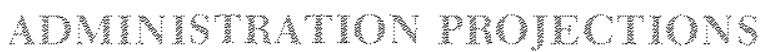

In sharp contrast to previous administrations, the present administration has explicitly spelled out a target path for monetary growth. It is therefore of

\footnotetext{
121982 CE A Report, pp. $49-50$.

13!hid., p. 206.

${ }^{14}$ lbid, p. 26 .
} 


\section{Table 2}

\section{Administration's Economic Projections: 1982-87 (from fiscal 1983 budget)}

\begin{tabular}{|c|c|c|c|c|c|}
\hline & $\begin{array}{c}\text { GNP } \\
\text { (billons of } \\
\text { doltars) }\end{array}$ & $\begin{array}{l}\text { Peal GNP } \\
\text { (billions of } \\
\text { } 972 \text { dollars) }\end{array}$ & $\begin{array}{l}\text { Prices } \\
(1972=100)\end{array}$ & $\begin{array}{l}\text { Unemploymen } \\
\text { rate }\end{array}$ & $\begin{array}{l}\text { M1 } \\
\text { (bilions of } \\
\text { dollars) }\end{array}$ \\
\hline IV/1981 Actual & $\begin{array}{r}\$ 2995 \\
(9.7)\end{array}$ & $\begin{array}{r}\$ 1498 \\
(0.8)\end{array}$ & $\begin{array}{l}200.0 \\
(8.8)\end{array}$ & $8.4 \%$ & $\begin{array}{r}\$ 436.7 \\
(5.0)\end{array}$ \\
\hline W/1982 & $\begin{array}{r}3307 \\
(104)\end{array}$ & $\begin{array}{l}1543 \\
(3.0)\end{array}$ & $\begin{array}{l}214.4 \\
(7.2)\end{array}$ & 8.4 & $\begin{array}{l}457.4 \\
(4.7)\end{array}$ \\
\hline IV/1983 & $\begin{array}{l}3671 \\
(11,0)\end{array}$ & $\begin{array}{l}1623 \\
(5.2)\end{array}$ & $\begin{array}{r}226.2 \\
(5.5)\end{array}$ & 7.6 & $\begin{array}{r}477.9 \\
(45)\end{array}$ \\
\hline IV/1984 & $\begin{array}{l}4038 \\
(10.0)\end{array}$ & $\begin{array}{l}1702 \\
(4: 9)\end{array}$ & $\begin{array}{l}237.2 \\
(49)\end{array}$ & 68 & $\begin{array}{l}498.1 \\
(4.2)\end{array}$ \\
\hline IV/1985 & $\begin{array}{l}4417 \\
(9.4)\end{array}$ & $\begin{array}{l}1781 \\
(4.6)\end{array}$ & $\begin{array}{r}248.1 \\
(4.6)\end{array}$ & $6 . \dot{2}$ & $\begin{array}{l}517.8 \\
(4.0)\end{array}$ \\
\hline IV/1986 & $\begin{array}{l}4819 \\
(911)\end{array}$ & $\begin{array}{l}1857 \\
(43)\end{array}$ & $\begin{array}{l}259.5 \\
(4.6)\end{array}$ & 5.6 & $\begin{array}{l}537.0 \\
(37)\end{array}$ \\
\hline IV/1987 & $\begin{array}{l}5248 \\
(8.9)\end{array}$ & $\begin{array}{l}1937 \\
(4.3)\end{array}$ & $\begin{array}{l}270.9 \\
(4.4)\end{array}$ & 5.2 & $\begin{array}{l}555.5 \\
(3.4)\end{array}$ \\
\hline $1981-87$ & $(9.8)$ & $(4.4)$ & $(5.2)$ & 6.6 & $(4.1)$ \\
\hline
\end{tabular}

NOTE All GNP data adjusted to February 1982 reviston of NIA accounts $M 1$ reflects revision. of February 1982. M1 figures correspond to monetary policy assumption stated in the 1982 CEA Report.

Rates of change in parentheses.

interest to see how the administration's projections compare with those derived from an explicitly monetarist model. The framework used for this comparison is a revised and updated version of the "St. Louis model."'15

According to the St. Louis model, nominal GNP is detemined directly by a reduced-fom equation relating the percent change in GNP to current and past changes in money (MI) and high-employment federal expenditures (national income accounts basis). Estimates of this equation indicate that the growth of federal spending has little net effect on GNP over a period of a year or more. ${ }^{16}$ The primary factors affecting GNP growth are the rate of change of money and trend velocity, as embodied in the coefficients of the equation.

\footnotetext{
${ }^{15}$ For a discussion of the original nodel, see Leonall C. Andersen and Keith M. Carlson, "A Monetarist Model for Eonomic Stabilization," this Review (April 1970), pp. 7-25. For a detailed stmmany of the model in revised and npdated form, see the appendix.

${ }^{16}$ For a recent study of the impact of fiscal actions on GNP, see $R$. W. Hafer, "The Role of Fiscal Policy in the St, Louis Equation," this Review (0amuary 1982), pp. 17-22.
}

The change in GNP is distributed between changes in the price level and output via a price equation. The price equation specifies the percent change in the GNP deflator as a function of energy prices, demand pressure and the recent history of price change. ${ }^{17}$ Over the long rum, the estimated change in the price level is dominated by the trend of money growth. Given the change in GNP and the change in the price level, the change in output is found via the GNP identity; that is, GNP equals price level times output.

The unemployment rate also is solved for as a part of the St. Louis model. Estimated changes in output along with assumptions about the growth of potential output provide the basis for calculating the unemployment rate via Okun's Law. ${ }^{18}$

\footnotetext{
17 For a further aiscussion of the role of energy prices in the determination of the price level, see John A. Taton, "Energy Prices and Short-Rum Economic: Performance," this Pirticit (January 1981), pp. 3-17

18Arthm M. Okm, "Potential GNP: Its Measurement and Signifcence," 1962 procedings of the Bushess and Economic Statistics Section of the American Statistical Association, pp. 98-104.
} 
Table 3

St. Louis Model Projections for 1976-81: An Ex Post Comparison

\begin{tabular}{|c|c|c|c|c|c|}
\hline \multicolumn{6}{|c|}{ Administration Projections as of Mid-1977 } \\
\hline & GNP & Bea GNP & Prices & Unemployment rate & N1 \\
\hline 1976 Actual & $116 \%$ & $60 \%$ & $53 \%$ & $77 \%$ & No \\
\hline 197 & 113 & 51 & 59 & 70 & expliont \\
\hline 1978 & 119 & 53 & 63 & 63 & assumplion \\
\hline 1979 & 113 & 50 & 61 & 57 & \\
\hline 1980 & 10.6 & 52 & 6.1 & 52 & \\
\hline 1981 & 98 & 49 & 4.3 & 48 & \\
\hline 1982 & 8.6 & 43 & 12 & 45 & \\
\hline 197681 & 110 & 51 & 55 & 61 & \\
\hline
\end{tabular}

1977 St Louis Model Prolections with Administration GiNP Path

\begin{tabular}{|c|c|c|c|c|c|}
\hline & GNP & Bed GNP & Prices & Uhenployment, rte & 11 \\
\hline 1976 Actual & $116 \%$ & $60 \%$ & $53 \%$ & $77 \%$ & 50 \\
\hline 1977 & 112 & 5\%? & 37 & 71 & 6.0 \\
\hline 1978 & 121 & 57 & 61 & 61 & 77 \\
\hline 1979 & 111 & 45 & 65 & 57 & 78 \\
\hline 1980 & 107 & 29 & 76 & 56 & 68 \\
\hline 198: & 97 & 05 & 97 & 65 & 60 \\
\hline 1982 & 87 & 08 & 95 & 82 & 51 \\
\hline 197600 & 110 & 38 & 70 & 6.5 & 70 \\
\hline
\end{tabular}

4
4

NoJE Adninistration and st Louls Model prolections teken rom November 1977 fevew.

To illustrate the projection performance of the St. Louis model, table 3 presents an ex post summary of projections made in this Retiew in the fall of 1977.19 The relevant projection period at that time was 1977 . 81. The administration's GNP projections at that time implied a path of declining growth in money, a

\footnotetext{
${ }^{19}$ Keith M. Carlson, "Economic Gouls for 1981: A Monetury Analysis," this Reviet (November 1977), pp. 2-7. The major differences in the model wsed at that time and the version described in the appendix are in the treatment of energy prices and the adjustment for seral correlation.
}

path that was used in simulating the St. Louis model. Since the actual path of monetary expansion was similar to that asstumed in simulating the model and that implicit in the administration's projections, the growth of GNP was forecast with considerable accuracy by both the administration and the model. There were differences, however, between the administration's and the St. Lonis model's forecasts for real GNP, the price level and the unemployment rate, particularly after 1978 . In contrast to the administration's forecast, the model projected a slow- 


\section{Table 4}

\section{St. Louis Model Simulations: 1982-87 (assuming administration's GNP path)}

\begin{tabular}{|c|c|c|c|c|c|}
\hline & $\begin{array}{l}\text { GNP } \\
\text { (oillons of } \\
\text { dollars) }\end{array}$ & $\begin{array}{l}\text { peal GNP } \\
\text { (bllions of } \\
1972 \text { odllers) }\end{array}$ & $\begin{array}{l}p r c e s \\
1972-100)\end{array}$ & Unemploy men & $\begin{array}{l}\text { Mt } \\
\text { doflons of }\end{array}$ \\
\hline W/198/ Actual & $\begin{array}{r}\$ 2905 \\
(97)\end{array}$ & $\begin{array}{l}81498 \\
(08)\end{array}$ & 2000 & $84 \%$ & $\begin{array}{r}\$ 467 \\
(50)\end{array}$ \\
\hline N/1982 & 3306 & 1578 & $2+51$ & 88 & 4712 \\
\hline V/9983 & 3670 & 1603 . & 2291 & 81 & 5070 \\
\hline$N / 1984$ & 4037 & 1662 & $\begin{array}{r}2432 \\
(6,2)\end{array}$ & 77 & 5400 \\
\hline W/1985 & $\begin{array}{l}4416 \\
(8,4)\end{array}$ & $\begin{array}{l}720 \\
(35)\end{array}$ & $\begin{array}{l}257, \\
(5.7)\end{array}$ & 75 & $\begin{array}{l}5729 \\
61)\end{array}$ \\
\hline U/1986 & 4819 & $(38)$ & 2702 & 72 & 6067 \\
\hline W/1987 & 8249 & $(461)$ & 2828 & 68 & $6 4 \longdiv { 3 }$ \\
\hline 1981,87 & $(\theta, 8)$ & $(37)$ & $(59)$ & 77 & $(66)$ \\
\hline
\end{tabular}

thates of ehange n parentheses:

ing in output and an acceleration of the price level in the latter part of the period, both of which occured.

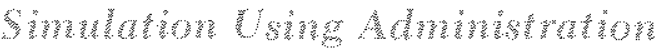

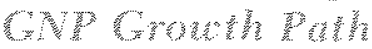

The first issue addressed here is the feasibility of the output and inflation scenarios. The analysis does not, at this point, examine the question whether GNP can be attained with the administration monetary assumptions; it focuses exclusively on its projections of inflation and output growth, given its path for the growth of GNP. The assumptions used for the other exogenous variables in the St. Louis model are as follows: potential GNP is assumed to grow 3.3 percent per year from late 1981; growth in highemployment federal expenditures is projected at 6.3 percent per year; and the change in the relative price of energy is assumed to be zero. ${ }^{20}$

\footnotetext{
20These assumptions are designed to be consistent with the administration's, even though they do not provide specific estimates of the se variables in either the CEA Report or the Fiscal 1982 Budget. For a discussion of prospects for eal CNP growth, see 1982 CEA Report, pp. 115-17.
}

The results of this simulation, shown in table 4 , should be compared with those in table 2 . It should be noted first that the path of money growth required to attain the administration's projected GNP path is substantially higher than what they explicitly state as desired. Assuming that this GNP path is attaned, however, the St. Louis model indicates that the administration's projections are indeed optimistic. The model indicates an unemployment rate of 6.8 percent in late 1987 in contrast to the administration's projected 5.2 percent rate, with annual real growth averaging 0.7 percent lower for the model simulation. The model is also more pessimistic on inflation, indicating an annual average inflation rate of 5.9 percent instead of the administration's estimated 5.2 percent.

\section{Alernative Simulations}

Since the administration explicitly supports a monetary policy of gradual reduction in the rate of monetary growth, the results of this scenario, in which Ml growth is reduced gradually and steadily to a 3.7 percent rate in 1986 , are summarized in table? 5. All other assumptions are the same as in the previous simulation. 
As might be expected, the model shows a growth rate of nominal GNP much less than the administration has projected (compare with table 2). The CEA is aware of this diserepancy, but does not explain why the assumed growth of velocity should far exceed its historical rates of growth (see chart 2). ${ }^{21}$ For this scenario of a gradual reduction of money growth, the model indicates that the administration's inflation goal is easily achieved; in fact, the simulated inflation rate falls well below the administration's projected rate after 1983.22 The simulated path for real GNP, however, is considerably different than the administration has projected. In the early years, 1982-84, the model simulates much slower output growth, followed by faster growth in the later years. As a result, the simulated unemployment rate is still at a high 6.9 percent in late 1987 compared with an administration estimate of 5.2 percent.

Finally, a third simulation was run, based on a constant 5 percent annual grow th in money through 1987. The results are shown in table 6 . This steady money growth path comes closer to attaining both of the administration's inflation and unemployment goals than either of the simulations summarized in tables 4 and 5 . With steady 5 percent money growth, inflation averages 3.9 percent per year for the projection period, and the unemployment rate is brought to near 6 percent by late 1987 .

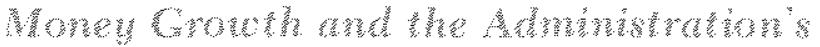

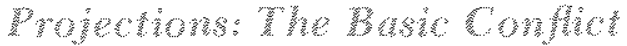

The administration has emphasized that it is important to establish credibility in economic policy in order to "break the back" of inflation expectations. Behind this strategy is the presumption that, if inflation can be reduced more rapidly than past relationships would indicate (e.g., faster than is embodied in the estimates from St. Louis model), greater output growth would result. This prospect would produce a brighter outlook for the interim years than shown in the simulations employing gradual money reduction (table 5). There is little likelihood, however, that the unemployment rate would be reduced to as low as the administration's estimate of 5 percent.

\footnotetext{
21 See footnote 9

22Over the long run in the St. Lonis model, the inflation rate approximates the rate of monetary growth. Prior to the achievement of this equilibrim, however, the St. Louis model oscillates.
}

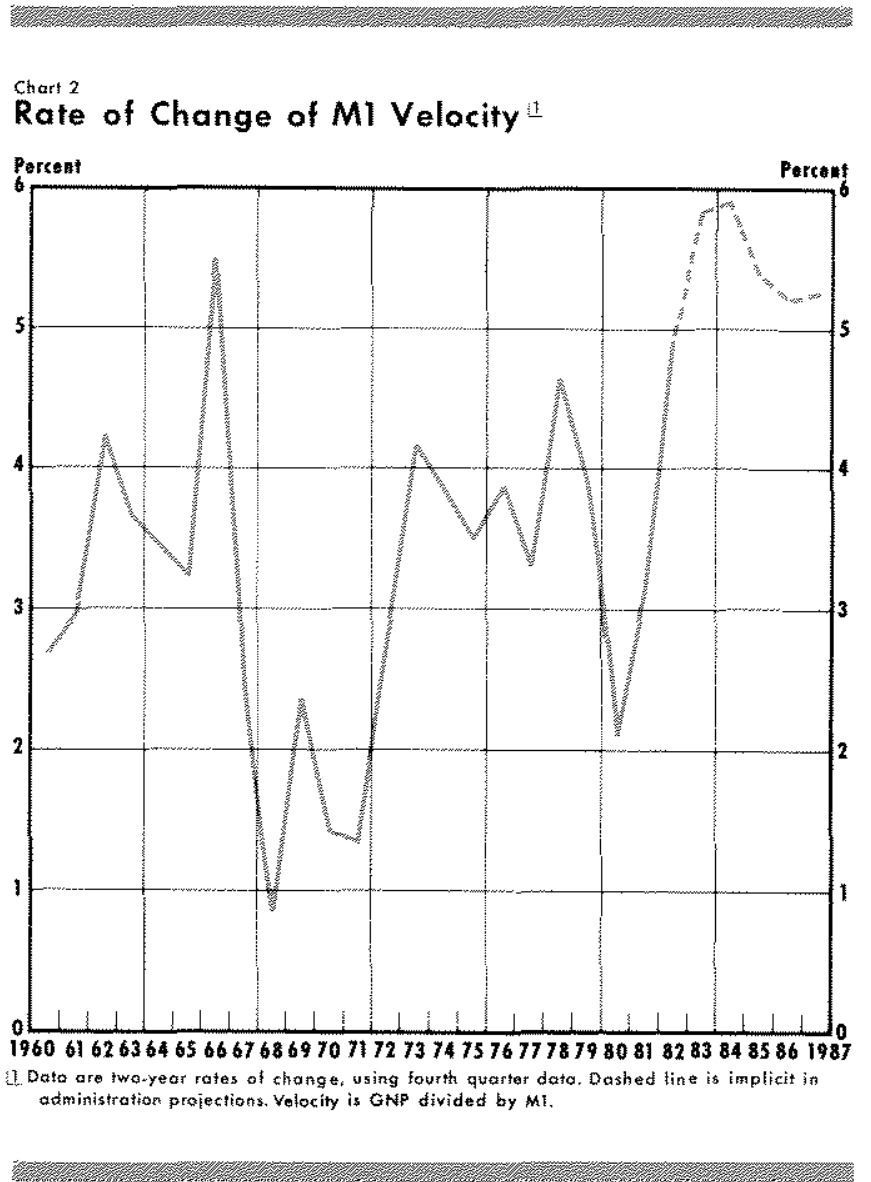

The more fundamental question yet to be answered is how the administration expects GNP to grow rapidly if money growth gradually declines. With the administration making explicit statements about interest rates falling in future years, apparently the result of declining inflation, velocity growth might be expected to slow rather than accelerate. Furthermore, velocity grow th historically has been remarkably stable over time, an observation that the CEA itself has emphasized. ${ }^{23}$ Thus, while the output-inflation breakdown of GNP in the St. Lou is model may be open to question, there seems to be little reason to question its GNP projections.

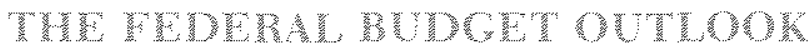

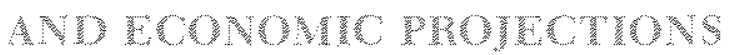

The administration's economic projections are of interest because they indicate how the nation's economic welfare can be expected to change in coming years. They are also of interest because of their impact on estimates of the budget deficit. The

\footnotetext{
zasee footnote 9.
} 
Table 5

St. Louis Model Simulations: 1982-87 (assuming declining growth rate of money from 5.0 percent rate in 1981-82)!

\begin{tabular}{|c|c|c|c|c|c|}
\hline & $\begin{array}{l}\text { onP } \\
\text { (bllloms of } \\
\text { dollars) }\end{array}$ & $\begin{array}{l}\text { Real GNP } \\
\text { (bilions of } \\
1972 \text { dollars) }\end{array}$ & $\begin{array}{l}\text { Plces } \\
1972-100)\end{array}$ & $\begin{array}{l}\text { Unemployment } \\
\text { fate }\end{array}$ & $\begin{array}{l}\text { MI } \\
\text { biltons of } \\
\text { dollars) }\end{array}$ \\
\hline V/1981 Actual & $\$ 2995$ & $\$ 1498$ & 2000 & $84 \%$ & 84367 \\
\hline N/1982 & 3227 & 1501 & 2150 & 97 & $\begin{array}{l}4574 \\
(47)\end{array}$ \\
\hline W/1983 & $\begin{array}{l}342 \\
(76)\end{array}$ & $\begin{array}{l}1520 \\
(18)\end{array}$ & 2273 & 9.9 & 4779 \\
\hline W1984 & $\begin{array}{l}3727 \\
(73)\end{array}$ & $\begin{array}{l}1581 \\
(35)\end{array}$ & 2350 & $9 \%$ & 4981 \\
\hline $14 / 985$ & 8989 & $\begin{array}{r}1659 \\
(49)\end{array}$ & 2407 & 80 & 5178 \\
\hline 11986 & $\begin{array}{l}4259 \\
(6,6)\end{array}$ & 4754 & 2428 & 80 & 5070 \\
\hline 14987 & $(4534$ & $\begin{array}{l}1860 \\
(60)\end{array}$ & 2440 & 69 & $\left.\frac{555}{3} 4\right)$ \\
\hline 1981807 & 1721 & 37 & $(34)$ & 89 & $441)$ \\
\hline
\end{tabular}

Tates of change in parentheses.

\section{Table 6}

St. Louis Model Simulations: 1982-87 (assuming steady growth rate of money of 5.0 percent) ${ }^{1}$

\begin{tabular}{|c|c|c|c|c|c|}
\hline & $\begin{array}{l}\text { SNP } \\
\text { ofloms }\end{array}$ & $\begin{array}{l}\text { neal GNP } \\
\text { (bilons of } \\
1972 \text { dollars) }\end{array}$ & (19 & Unemployment & $\begin{array}{l}\text { Wilons of } \\
\text { dollars) }\end{array}$ \\
\hline W/981 Actual & $\$ 2995$ & $\begin{array}{r}\$ 1498 \\
(0.8)\end{array}$ & 2000 & $84 \%$ & $\$(5,36)$ \\
\hline W/1982 & 3230 & $\begin{array}{l}504 \\
(0,4)\end{array}$ & $\begin{array}{l}2150 \\
751\end{array}$ & 9,6 & 4586 \\
\hline W/1083 & $\begin{array}{l}3495 \\
(8) 1\end{array}$ & 153 & 2275 & 97 & 4815 \\
\hline W/1904 & $\begin{array}{l}3770 \\
(81)\end{array}$ & $\begin{array}{l}1580 \\
(4.0)\end{array}$ & $\begin{array}{l}2366 \\
(40)\end{array}$ & 83 & $\begin{array}{l}5056 \\
(50)\end{array}$ \\
\hline W/1985 & $\begin{array}{l}4085 \\
(8,1)\end{array}$ & 1683 & 240 & 84 & 5308 \\
\hline W/ 886 & $\begin{array}{r}446 \\
811\end{array}$ & $\begin{array}{l}1784 \\
(60)\end{array}$ & $247 \%$ & 73 & $\begin{array}{l}5574 \\
(50)\end{array}$ \\
\hline $1 \mathrm{~N} / 987$ & $\begin{array}{l}4774 \\
811\end{array}$ & $\begin{array}{l}1895 \\
(6.2)\end{array}$ & $\begin{array}{l}2523 \\
(18)\end{array}$ & 61 & $\begin{array}{l}5853 \\
(5,0)\end{array}$ \\
\hline $1981-87$ & $(8,1)$ & $(4.0)$ & $(39)$ & 8,4 & $(5,0)$ \\
\hline
\end{tabular}

Thates of change in parentheses. 


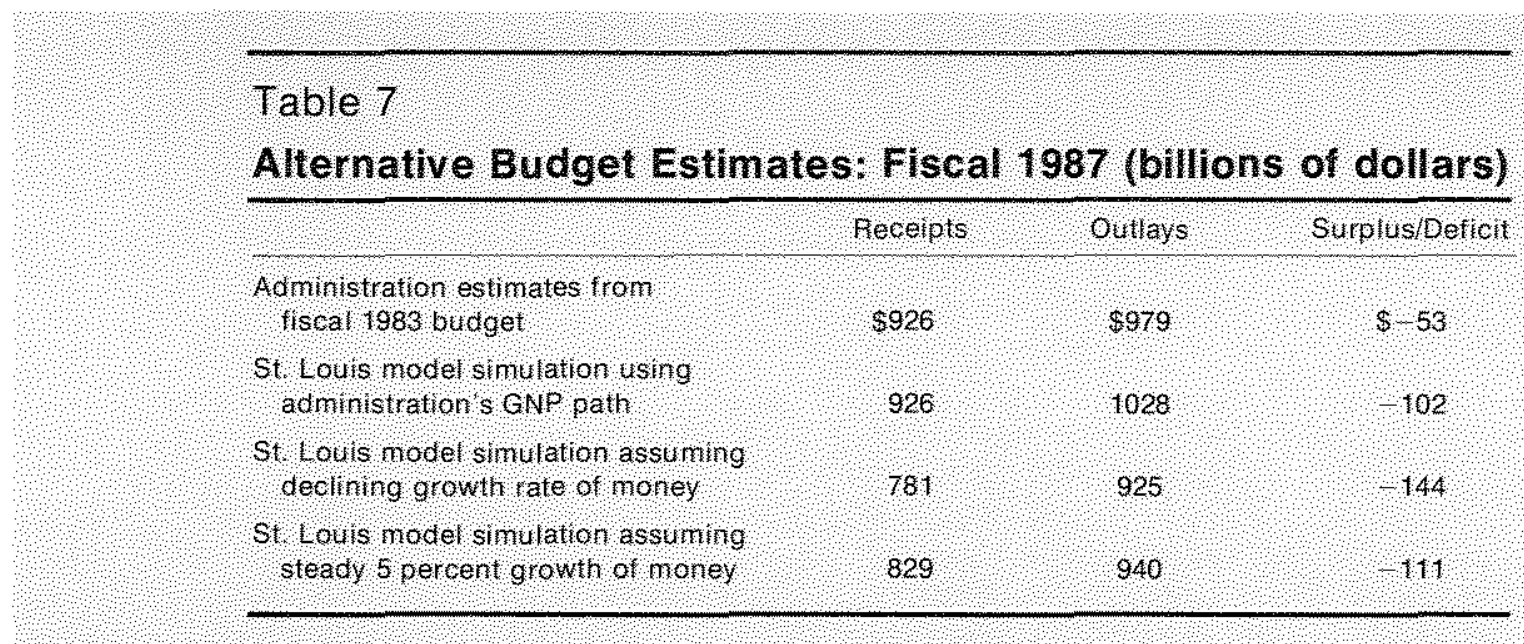

size of prospective deficits has become an issue among economic analysts, presumably because they consider it an indicator of the government's impact on eredit markets and, thus, on long-term economic growth. ${ }^{24}$ However, as is shown below, the process of estimating the deficit is an imprecise exercise.

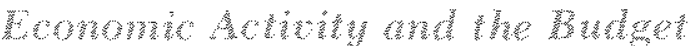

Although the effect of the budget on economic growth is still an open issue, there is no question that the budget is sensitive to the pace of economic activity. This relationship received added emphasis in this year's budget document as budget figures appear to have become more and more sensitive to economic conditions.

In prior years, analyses of the connection between the budget and the economy focused on government revenues. Given our tax laws, different revenue estimates depend on the assumptions made about GNP and such related indicators as wages and salaries, and corporate profits. The relationship still holds, of conrse, but the size of today's economy is so large that a given growth rate of $\mathrm{GNP}$ translates into a much different dollar amount of federal revenues than it did just a few years ago. This relationship between GNP and government reventes is important because public attention seems to focus on the dollar size of the federal defiet.

\footnotetext{
24 Such an effect is not in the $S 2$. Fouis model; incorporation of this presumed relationshe between the size of the deficit and the rate of economic growth wouk recuire specifying potential ontputas a function of either the size of the deficit or the size of government. The only role for federel deficits in the $S t$ Louis model is their possible relation hip to the rate of money grow th.
}

At the same time, federal outlays have become increasingly sensitive to variations in economic activity. The usual effect via unemployment insurance continues to operate, but, like the revenue side, a given unemployment rate now involves a greater amount of dollar expenditures than before. In addition, atomatic changes in outlays for a number of welfare programs occur when the economy slows down or speeds up. In fact, approximately 30 percent of federal outlays now are indexed to inflation. Finally, interest payments on the national debt, an important endogenous component of the budget, reffect both the size of the deficit and the level of interest rates.

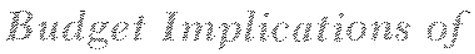 A}

To examine the sensitivity of budget estimates to alternative economic assumptions, budget equations were added to the St. Loutis model. The growth of receipts was specified as a function of the growth of nominal GNP, using the elastieity implied in the administration's budget docment. ${ }^{25}$ The growth of ontlays was expressed as a function of the growth of output and the rise in prices, again using the relevant elasticities from the budget docment.

Table 7 summarizes the budget results for fiscal 1987 for all three simulations. Only results for fiscal

\footnotetext{
25Fised 1983 Budget pp. 2:6-13. The implied elsticties are foum by comparing the budget effects of the economic

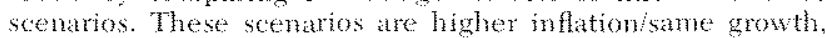
higher rrowllower inflation, and lower growth higher infla fion, with all altematives defned with relerence to the

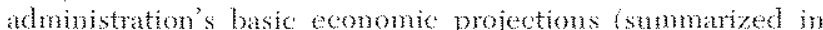
table 2 .
} 
1987 are given to ease the comparison of alternative policy scenarios. Moreover, focusing on 1987 illustrates the imprecision that encompasses any budget estimates, because a small change in grow th rates can translate into a difference of many billions of dollars. All simulations assume that the basic proposals contained in the fiscal 1983 budget are enacted. ${ }^{26}$ The differences in results reflect only the impact of differing economic assumptions.

The first simulation, using the administration's GNP path as shown in table 4, yields a deficit of $\$ 102$ billion; the administration estimates $\$ 53$ billion. The estimate for receipts is the same as the administration's because the grow th of nominal GNP is the same. Outlays are higher for this simulation because of higher inflation estimates, which push up outlays for indexed programs, and lower real growth estimates, which boost outlays for unemployment compensation and other unemployment-related welfare programs.

The second simulation, based on a gradual reduction of money growth (see table 5), yields a much larger deficit in 1987 than the administration projects. Outlays are less than projected by the administration because inflation is slower, but receipts fall

26r This also assumes the Economic Recovery Tax Act of 1981 is left intact. The basic proposals themselves have been revised since February, but details await the outcome of negotiations between Congress and the administration. The purpose of the estimates presented here is to illustrate the budget impact of alternative economic assumptions without actually attempting to forecast the size of the deficit. even more sharply because the growth of nominal GNP is much less rapid. As a result, the deficit is estimated at $\$ 144$ billion for 1987 - despite the incorporation of the administration's proposals to reduce government programs in the 1983 budget.

The third simulation, based on steady 5 percent money growth (see table 6), yields a slightly larger deficit than the simulation using the administration's GNP path. However, both outlays and receipts are lower than in that case.

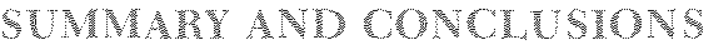

The administration has presented a controversial set of economic assumptions and budget projections for the years through 1987. Some simulations of a monetarist model, however, demonstrate that the administration's projections contain fundamental inconsistencies. Based on U.S. economic experience since 1960 ,

(1) the administration's estimates for GNP growth are inconsistent with its stated monetary tatgets; and

(2) given its GNP growth path, its estmates of real growth, memployment and, to a lesser extent, infiam tion appear too optinistic.

These conclusions also indicate that the administration's estimates of the size of the federal deficit are imprecise. Given the administration's budget plan, the pattem of declining growth in money that it supports will result in a deficit of about $\$ 144$ billion in $1987, \$ 93$ billion more than is projected in the fiscal 1983 budget. 


\section{Appendix Revised Form of St. Louis Model ${ }^{1}$}

The version of the St. Louis model used for the simulations in this article is summarized in table 1 , with the coefficients given in table 2. Equations I, 2 and 4 are estimated with Almon constraints on the coefficients. Equation 1 is estimated with ordinary least squares. Three characteristics differentiate this model from the original version published in 1970 ; (1) most variables are entered in rate-of-change form rather than first-difference form; (2) the demand

\section{Table 1}

\section{The Model}

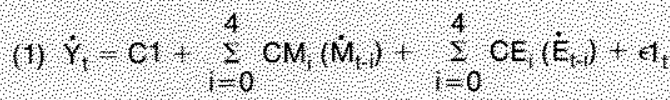

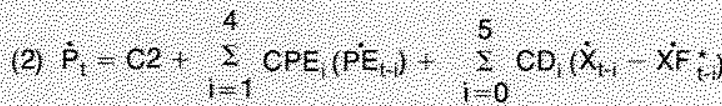

$$
\begin{aligned}
& \text { I CPA PAV }, \text { COUM (OUM) }
\end{aligned}
$$

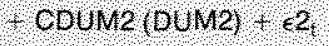

$$
\begin{aligned}
& \text { (3) } \mathrm{PA}_{1}=\frac{21}{4}, \mathrm{CPA},\left(\mathrm{P}_{1}\right)
\end{aligned}
$$

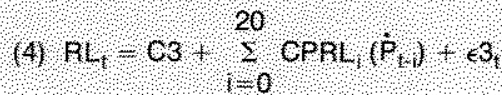

$$
\begin{aligned}
& \text { (5) } 4, u, F, C G(G A P), C G(G A P), A_{t} \\
& \text { (6) } Y, P(100)\left(X_{1}\right) \\
& 7 Y_{Y}=\left(Y_{1}, r^{4}, 1\right) 100 \\
& \text { (8) } x_{1}=\left(x_{1} x_{1}\right) 4>1,100 \\
& \text { (0) } 1,4(P, P, 1,1,100 \\
& \text { (10) } \left.\mathrm{GAP},\left(\mathrm{XF}, \mathrm{x}_{\mathrm{f}}\right) \mathrm{XF}\right) 100 \\
& (11)+4(x), x+4) 1,00
\end{aligned}
$$$$
Y \text { nominal GNP }
$$$$
\mathrm{M} \text { เ } \rightarrow \text { monoy stock }(\mathrm{MI})
$$$$
\mathrm{E},=\text { high employment expenditures }
$$

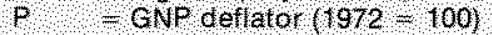$$
\mathrm{PE} \text {, retatwe price of energy }
$$$$
X \bullet \text { output in 1972 dollars. }
$$$$
\mathrm{xP} \text { - potentral output (Rasche/Tatom) }
$$$$
\mathrm{RL}, \text { corborate bond rate }
$$$$
\mathrm{O}+\text { unenplownert rate }
$$$$
\text { UF } \mathrm{F} \text { unemplovment rate at full enoloyment }
$$$$
\text { DUM1 = control dummy }(11 / 1971-1973=1,0 \text { elsewhere) }
$$$$
\text { DUM2 = post controldunny } / / 973 / 1975 / 1,0 \text { elsewhere }
$$

slack variable is entered in real rather than nominal tems; and (3) where relevant, the model's equations have been corrected for serial correlation problems.

\footnotetext{
${ }^{1}$ For further discussion, see Keith M. Carlson and Scott E. Hein, "An Analyss of a Modified St. Lotis Model," a paper prepared for the Spring Conference on Comparing the Predictive Perfomance of Macroeconomic Models at Washington University in St. Louis (April 20, 1982).
}

\section{Table 2}

In-Sample Estimation: 1/1960-IV/1980 (absolute value of $t$-statistic in parentheses)

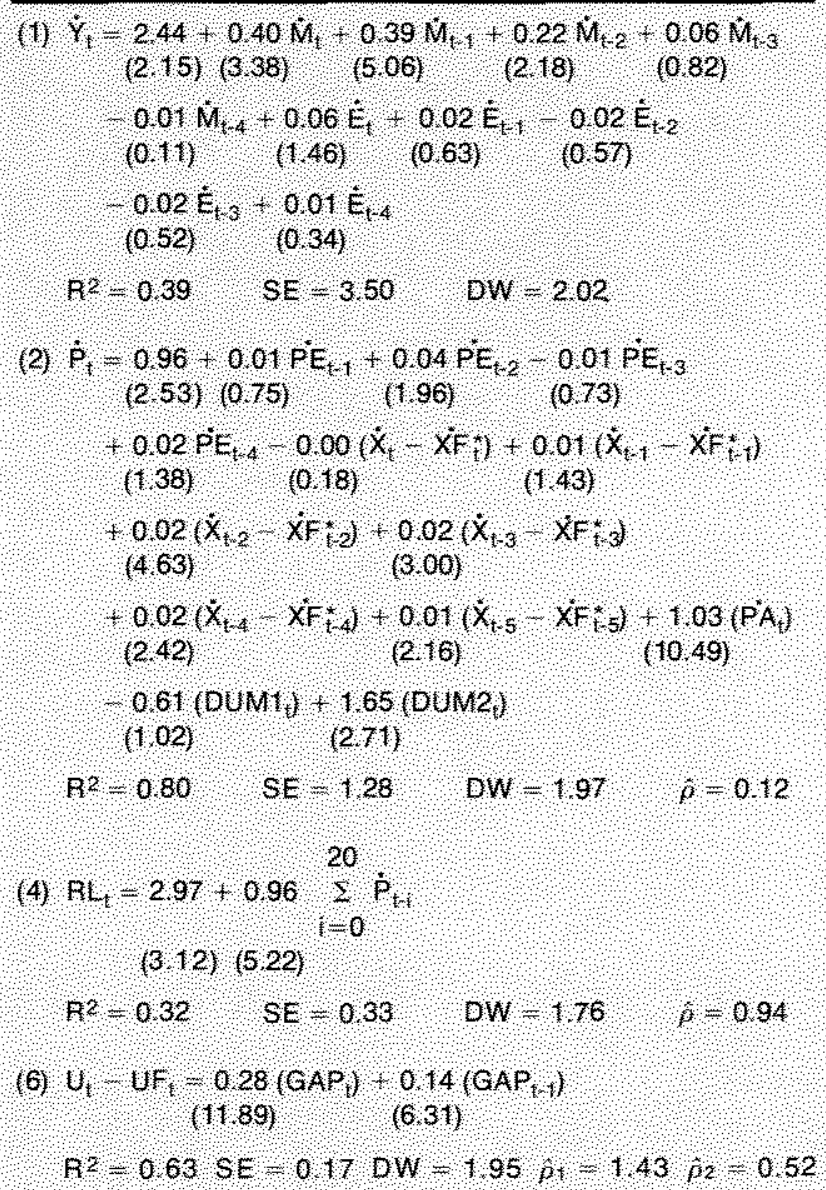

